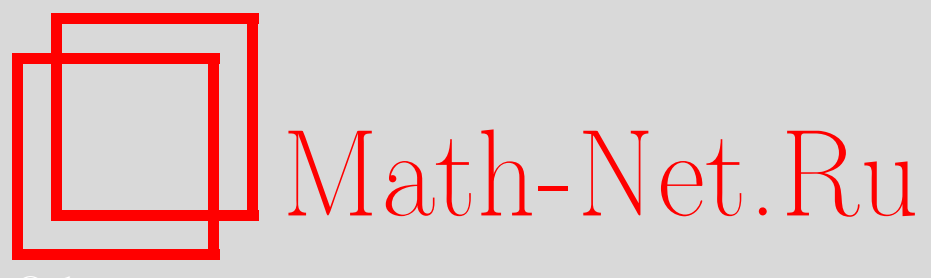

Ю. М. Березанский, В. П. Котляров, В. А. Марченко, К. В. Маслов, С. П. Новиков, Ф. С. РофеБекетов, А. М. Самойленко, Я. Г. Синай, Е. Я. Хруслов, М. В. Щербина, Леонид Андреевич Пастур (к 70-летию со дня рождения), УМН, 2008, том 63, выпуск 1, 190-191

DOI: https://doi.org/10.4213/rm9126

Использование Общероссийского математического портала Math-Net.Ru подразумевает, что вы прочитали и согласны с пользовательским соглашением http: //www . mathnet.ru/rus/agreement

Параметры загрузки:

IP : 52.87 .193 .239

26 апреля 2023 г., 14:09:13

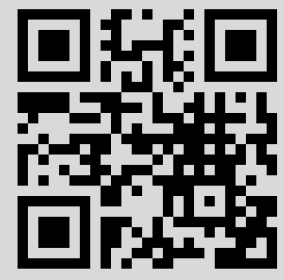




\section{Леонид Андреевич Пастур \\ (к семидесятилетию со дня рождения)}

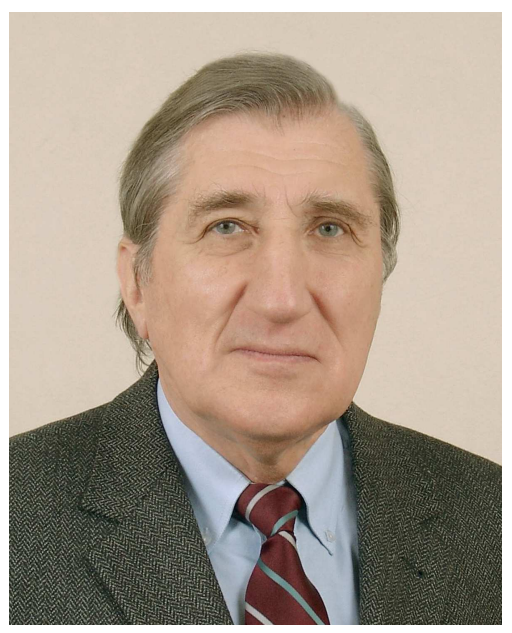

21 августа 2007 года исполнилось 70 лет выдающемуся математику Леониду Андреевичу Пастуру.

Л.А. Пастур родился в 1937 г. в Винницкой области. В 1955 г. по окончании средней школы в г. Мариуполе он приезжает в Харьков и поступает на инженерно-физический факультет Харьковского политехнического института. На этом факультете курсы математики и теоретической физики читались известными учеными и уровень подготовки студентов был чрезвычайно высок. У Л. А. Пастура с самого начала пробудился интерес к задачам теоретической физики, которые включали в себя трудные математические проблемы. Для его научного творчества навсегда стало характерным умение выделить в физической проблеме новые математические задачи и перспективные направления и применить к их исследованию современные математические методы.

После окончания института Л.А. Пастур поступает на работу в Физико-технический институт низких температур АН Украины в отдел математической физики, который возглавлял академик В.А. Марченко. В 1964 г. Л.А. Пастур защищает кандидатскую диссертацию, а в 1975 г. - докторскую диссертацию "Вопросы теории неупорядоченных систем”. С 1988 г. он заведует отделом статистических методов математической физики ФТИНТ АН Украины. В настоящее время Л.А. Пастур возглавляет отдел теоретической физики ФТИНТ им. Б. И. Веркина НАН Украины.

Основные научные интересы и наиболее значительные результаты Л. А. Пастура связаны со спектральной теорией случайных дифференциальных и конечно-разностных операторов, теорией случайных матриц, а также с математическими проблемами статистической физики и физики твердого тела. В начале научной деятельности Л. А. Пастур занимался дислокационной теорией двойникования в теории прочности твердых тел. Здесь им был получен ряд важных результатов, сразу замеченных и высоко оцененных физиками.

В середине 60-х годов под влиянием В. А. Марченко Л. А. Пастур начал заниматься исследованием спектральных свойств случайных матриц больших размерностей. В их совместной работе 1967 г. не только был получен ставший теперь классическим результат о распределении собственных значений ансамбля Вишарда, но и предложен метод, позволивший найти асимптотическое распределение собственных значений для целого класса ансамблей случайных матриц. Эта работа послужила началом целого цикла исследований Л. А. Пастура в теории случайных матриц, которые активно продолжаются и сейчас. В начале 90-х годов он одним из первых понял перспективность нового раздела теории случайных матриц - так называемых матричных моделей. Его 
работы с М. В. Щербиной о глобальном распределении собственных значений этих моделей и универсальности локального распределения собственных значений стали пионерскими в этой области. В них, в частности, была доказана гипотеза универсальности локального распределения собственных значений, сформулированная Дайсоном в 60-е годы для матричных моделей общего вида, но доказанная к тому времени лишь в нескольких частных случаях. Эти работы дали толчок бурному развитию математической теории матричных моделей, которое продолжается последнее десятилетие.

Обширный круг исследований Л. А. Пастура относится к спектральной теории самосопряженных дифференциальных и конечно-разностных операторов со случайными коэффициентами, где он выделил и исследовал важный класс случайных метрически-транзитивных операторов. Ему принадлежат классические результаты о критерии самосопряженности таких операторов, неслучайности спектра и его компонент, индексах дефекта и т.д. Результаты этих исследований изложены в монографии Л. А. Пастура и А. Фиготина "Spectra of random and almost-periodic operators". Одним из наиболее ярких результатов в спектральной теории случайных операторов является доказательство наличия чисто точечного спектра у оператора Шрёдингера со случайными коэффициентами.

В 1963 г. под влиянием выдающегося физика-теоретика И. М. Лившица Л. А. Пастур начал заниматься теорией неупорядоченных систем - новой областью физики твердого тела, имеющей дело с веществами, в которых отсутствует дальний структурный порядок (аморфные металлы и полупроводники, полимеры и т. п.). Основные результаты этих исследований были подытожены в монографии И. М. Лившица, С. А. Гредескула и Л. А. Пастура "Введение в теорию неупорядоченных систем". Они определяют современный облик этого раздела теоретической физики (методы вычисления кинетических характеристик, исследования флуктуационного и примесного спектра и т. д.). За эту книгу авторы были удостоены в 1985 г. Государственной премии Украины.

Среди других результатов Л. А. Пастура, относящихся к математическим проблемам теоретической физики, следует отметить работу по теории уравнений КирквудаЗальцбурга и большой цикл работ по теории неупорядоченных спиновых систем. В частности, в работах о параметре порядка в моделях среднего поля для спинового стекла были предложены новые методы, которые послужили началом интенсивных математических исследований в этой области и способствовали созданию математической теории нарушения репличной симметрии.

Круг научных интересов Л. А. Пастура очень широк. Он постоянно следит за всеми новыми научными достижениями не только в областях, близких к нему, но и в других разделах математики. Его необъятная эрудиция как в области математики, так и в области физики в сочетании с общительным характером и доброжелательностью привлекают к нему многочисленных учеников, успешно работающих сейчас как в Украине, так и в других странах.

Л. А. Пастур обладает незаурядными организаторскими способностями. Он долгие годы был заместителем директора ФТИНТ по науке. В настоящее время он является главным редактором журнала "Математическая физика, анализ, геометрия", входит в редколлегии еще нескольких научных журналов. В 1990 г. Л. А. Пастура избрали академиком Национальной академии наук Украины.

Свое семидесятилетие Леонид Андреевич встречает полный сил и творческих замыслов. Вместе с его многочисленными друзьями мы желаем ему здоровья и творческих успехов.

Ю. М. Березанский, В.П. Котляров, В.А. Марченко, К.В. Маслов, С.П. Новиков, Ф.С. Рофе-Бекетов, А. М. Самойленко, Я.Г. Синай, Е. Я. Хруслов, М.В. Щербина 